\title{
Abdellatif Laâbi, Écris la vie
}

\section{Ilaria Bruno}

\section{OpenEdition}

\section{Journals}

\section{Edizione digitale}

URL: https://journals.openedition.org/studifrancesi/46362

DOI: 10.4000/studifrancesi.46362

ISSN: 2427-5856

\section{Editore}

Rosenberg \& Sellier

\section{Edizione cartacea}

Data di pubblicazione: 1 octobre 2007

Paginazione: 484

ISSN: 0039-2944

\section{Notizia bibliografica digitale}

Ilaria Bruno, «Abdellatif Laâbi, Écris la vie», Studi Francesi [Online], 152 (LI | II) | 2007, online dal 30

novembre 2015, consultato il 24 novembre 2021. URL: http://journals.openedition.org/studifrancesi/ 46362 ; DOI: https://doi.org/10.4000/studifrancesi.46362

\section{Questo documento è stato generato automaticamente il 24 novembre 2021.}

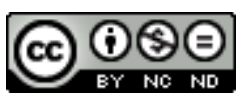

Studi Francesi è distribuita con Licenza Creative Commons Attribuzione - Non commerciale - Non opere derivate 4.0 Internazionale. 


\title{
Abdellatif Laâbi, Écris la vie
}

\author{
Ilaria Bruno
}

\section{NOTIZIA}

Abdellatif Laâbi, Écris la vie, Paris, La Différence, 2005, pp. 157.

1 Écris la vie è l'ultima raccolta poetica, o meglio l'ultima raccolta di riflessioni in versi dello scrittore marocchino Abdellatif Laâbi, una raccolta improntata alla filosofia del carpe diem. La suddivisione in dieci brevi sezioni costituisce un tentativo di dare un certo ordine all'affluire di pensieri che si affastellano nella mente del poeta, che vuole appunto scrivere la vita, la sua vita ma anche quella degli altri e, dunque, affrontare i gravi problemi del nostro tempo e del nostro mondo: la questione del velo, la liberazione di Florence Aubenas, gli attentati di Madrid... Il poeta abbandona volentieri il suo je narcisista e invadente, per concentrarsi sull'umanità intera e dar voce alle sue attese, alle sue paure e alle sue debolezze. Sono temi esistenziali, universali e attuali, quelli che s'intrecciano in questo scrigno di riflessioni in cui l'autore, con tono sarcastico, non perde occasione per attaccare «ces temps de pollution/des vocables et des signes» (p. 106). Per far fronte a questa indigestione verbale e simbolica in cui, secondo Laâbi, viviamo, egli propone alcune soluzioni, soprattutto nell'ultima parte della raccolta. Qui infatti il soggetto poetico si rivolge insistentemente a un tu generico per dargli vere e proprie lezioni di vita e consigli di scrittura, come il seguente, che riguarda la nascita e la natura della poesia: «Orphelin à la naissance | le poème est appelé à grandir seul | Il vivra sa vie | et mourra un jour | en se souciant comme d'une guigne | de ces recherches hasardeuses de paternité» (p. 127). 